\title{
RESEPSI MASYARAKAT DAN WISATAWAN TERHADAP KARYA SENI MURAL DI KAWASAN KRUENG DHO DAN KRUENG DAROY KOTA BANDA ACEH
}

\author{
Susandro $^{1^{*}}$, Hatmi Negria Taruan ${ }^{2 *}$, Muhammad Ghifari ${ }^{3 *}$ \\ Program Studi Seni Teater ${ }^{*}$, Program Studi Seni Rupa dan Desain ${ }^{2 *}$, \\ Program Studi Desain Komunikasi Visual ${ }^{3 *}$ \\ Jurusan Seni Pertunjukan ${ }^{1 *}$, Jurusan Seni Rupa dan Desain ${ }^{2}$ dan 3* \\ Institut Seni Budaya Indonesia (ISBI) Aceh \\ Jl. Transmigrasi, Gampong Bukit Meusara, Kec. Kota Jantho, Kab. Aceh Besar, 23911. \\ Aceh. Indonesia \\ Email: susandro@isbiaceh.ac.id
}

\begin{abstract}
Abstrak
Karya seni mural berkemungkinan dapat mendorong meningkatkan kepariwisataan, hingga sejalan dengan meningkatnya perekonomian suatu masyarakat atau perihal lainnya. Namun, persoalannya ialah karya seni mural bertentangan dengan suatu ketentuan, khususnya sebagaimana yang terdapat dalam syariat Islam. Secara jelas dinyatakan dalam syariat Islam, dilarang membuat gambar yang menyerupai makhluk yang bernyawa atau memiliki ruh, seperti gambar manusia dan hewan. Akan tetapi, gambar tersebut dapat ditemui di pagar dan dinding-dinding rumah warga di bantaran Krueng Dho dan Krueng Daroy, Kota Banda Aceh. Faktanya, Aceh merupakan satu-satunya provinsi di Indonesia yang menjadikan syariat Islam sebagai landasan hukum Peraturan Daerah. Tujuan penelitian ini tidak bermaksud 'memperuncing' kontradiktif tersebut, melainkan ingin mengetahui pandangan masyarakat terhadap karya seni mural dari perspektif Islami dan berbagai kemungkinan dampak lainnya. Guna mencapai tujuan tersebut, penelitian dilaksanakan dengan metode deskriptif kualitatif. Data dikumpulkan dengan cara observasi, melakukan wawancara - terencana maupun tidak terencana - kepada masyarakat yang dianggap relevan, serta studi pustaka. Kemudian hasil penelitian dibangun berdasarkan analisis terhadap data, paparan bagaimana resepsi masyarakat terhadap karya seni mural dari sudut pandang syariat Islam.
\end{abstract}

Kata Kunci: syariat Islam, mural, kontradiktif, resepsi.

\begin{abstract}
Mural art is most likely to be able to encourage increased tourism, so that it is in line with plans to increase people's income or other matters. However, the question is the mural art which is opposed to the provisions, especially those relating to Islamic law. Clearly stated in Islamic Shari'a, released images are released that have life or spirit, such as pictures of humans and animals. However, the picture can be found on the fence and walls of the houses of the residents on the banks of Krueng Dho and Krueng Daroy, Banda Aceh City. In fact, Aceh is the only province in Indonesia that makes Islamic Sharia a legal basis for Regional Regulations. The purpose of this study is not to discuss 'trusting' these contradictions, discussing the public about mural works from an Islamic perspective and various other perspective changes. In order to achieve this goal, the study was conducted using descriptive qualitative methods. Data is collected by observation, conducting interviews - unplanned - for the community considered relevant, as well as literature study. Then the research results are built based on an analysis of the data, a presentation about the community of mural art from the perspective of Islamic law.
\end{abstract}

Keywords: Islamic sharia, murals, contradictions, receptions.

\section{PENDAHULUAN}

Secara etimologi, mural berasal dari bahasa latin yaitu murus yang berarti dinding. Mural adalah lukisan besar yang mendukung arsitektur (Mike Susanto, 2012: 4). Mural dapat juga disebut sebagai lukisan yang dibuat pada dinding (interior atau eksterior), langit-langit, atau bidang datar lainnya sebagai elemen dari suatu bangunan (Obed Bima Wicandra, 2009). Namun perlu ditekankan, mural berbeda dengan grafiti, meskipun keduanya diekspresikan pada media yang sama, yaitu dinding. Mural ialah gambar yang dibuat lebih bebas dan luas, atau secara spesifik berupa benda atau makhluk. Sedangkan grafiti ialah coretan-coretan pada dinding yang menggunakan komposisi warna, garis, bentuk, dan volume untuk menuliskan kata, simbol atau kalimat tertentu. 
Sebagian dari karya mural mengandung makna tertentu yang bertujuan mengedukasi orang banyak. Tidak hanya berfungsi menyampaikan suatu makna. Sebaliknya, karya seni juga dapat dimaknai dengan baragam makna. Makna tidak hanya disematkan oleh pengkaryanya saja, melainkan juga muncul dari orangorang yang menikmatinya. Pendek kata, penikmat dapat memaknai karya seni mural sebagaimana jangkauan imajinasi, pengetahuan, ilmu dan pemahamannya sehingga karya seni mural tersebut dapat diterima oleh masyarakat.

Karya seni mural yang dimaksud sebagai objek material penelitian ini terdapat di pagar dan dinding rumah warga sepanjang bantaran Krueng Dho dan Krueng Daroy, Dusun Kerinci, Gampong Seutui, Kota Banda Aceh. Karya seni mural tersebut merupakan hasil kreasi mahasiswa dan dosen Jurusan Seni Rupa dan Desain ISBI Aceh serta masyarakat setempat. Karya seni mural di bantaran Krueng Dho dikerjakan oleh dosen, mahasiswa, dan masyarakat setempat pada tanggal 24-25 Desember 2018. Kemudian berlanjut dengan pengerjaan karya seni mural di pemukiman warga bantaran Krueng Daroy kawasan Seutui Banda Aceh dalam rentang waktu 02-07 Maret 2019 yang sepenuhnya dikerjakan oleh dosen dan mahasiswa.

Penentuan objek material tersebut berdasarkan pada beberapa alasan dalam bentuk pertanyaan, yaitu: 1) bagaimana dampak karya seni mural terhadap masyarakat, baik secara ekonomi dan kepariwisataan, dan 2) mengapa (membuat) gambar makhluk hidup yang bernyawa atau memiliki ruh dapat diterima di tengah aturan, hukum atau qanun yang berlaku dalam kehidupan masyarakat Aceh yang berlandaskan pada syariat Islam. Perlu diketahui, masyarakat Aceh menjadikan syariat Islam sebagai landasan/pedoman hidup yang tercantum dalam Peraturan Daerah atau Qanun dimulai semenjak tahun 2002 (https://id.wikipedia.org/wiki/Hukum_jinayat_di_Ace h).

Kenyataannya, masyarakat di Kota Banda Aceh (khususnya di bantaran Krueng Dho dan Krueng Daroy) justru menerima karya seni mural ada di sekitar mereka, di tembok pagar dan dinding-dinding rumah. Bentuk dari karya seni mural tersebut pun beragam, di antaranya terutama ada yang menyerupai makhluk hidup yang bernyawa (memiliki ruh), seperti gambar manusia yang mengisahkan suatu peristiwa secara runtut berlatar belakang gambar hamparan alam yang luas. Di beberapa ruang lainnya sangat jelas terdapat gambar beberapa ekor binatang, seperti; burung, ikan, hiu dan kupu-kupu.
Gorga Jurnal Seni Rupa

Volume 09 Nomor 01 Januari-Juni 2020

p-ISSN: 2301-5942 | e-ISSN: 2580-2380

Penulis tekankan, penelitian ini tidak bermaksud mengedepankan kontradiksi tersebut. Namun mencoba menelusuri di balik itu, bagaimana pemahaman serta fungsi karya seni mural bagi masyarakat di bantaran Krueng Dho dan Krueng Daroy, Kota Banda Aceh.

\section{KAJIAN TEORI}

Resepsi merupakan suatu teori yang muncul dan berkembang dalam ranah seni sastra. Teori tersebut membuka ruang proses pemaknaan karya seni menjadi lebih luas, dimana makna dari karya seni tidak mutlak terdapat dari karya itu sendiri, melainkan juga dapat diberi makna oleh pembaca. Selanjutnya, berhubung objek material penelitian ini karya seni mural, dapat dipahami bahwa frasa 'seni sastra' dimaksudkan atau dipadankan sebagai karya 'seni mural.'

Resepsi sastra diterjemahkan dari istilah rezeptionaesthetik (Umar Junus, 1985). Menurut Norman Holland (dalam Umar Junus, 1985) istilah tersebut kurang lebih dapat dipadankan dengan literary response. Mungkin juga dapat diterjemahkan sebagai 'penerimaan estetik' sesuai dengan aesthetic of reception. Senada dengan itu, Franco Meregalli (dalam Umar Junus, 1985) menyatakan bahwa karena mulanya material kajian teori ini berlandaskan pada karya sastra, maka istilah-istilah yang disebutkan di atas diterjemahkan kembali menjadi resepsi sastra.

Umar Junus (1985) menyatakan resepsi sastra dimaksudkan bagaimana "pembaca" memberikan makna terhadap karya sastra yang dibacanya, sehingga dapat memberikan reaksi atau tanggapan terhadapnya. Tanggapan itu mungkin bersifat pasif, yaitu bagaimana seorang pembaca dapat memahami karya itu, atau melihat hakikat estetika yang ada di dalamnya. Atau mungkin bersifat aktif, yaitu bagaimana ia "merealisasikan"-nya.

Seturut dengan itu, Pradopo (2007) mengungkapkan bahwa resepsi merupakan ilmu keindahan yang didasarkan pada tanggapan-tanggapan pembaca terhadap karya sastra. Senada dengan itu, Teeuw (dalam Pradopo, 2007) menyatakan bahwa resepsi termasuk dalam orientasi pragmatik. Karya sastra sangat erat hubungannya dengan pembaca, karena karya sastra ditujukan kepada kepentingan pembaca sebagai menikmat karya sastra. Selain itu, pembaca juga yang menentukan makna dan nilai dari karya sastra, sehingga karya sastra mempunyai nilai karena adanya pembaca yang memaknai.

Salah satu tokoh yang memberi pengaruh besar (sekaligus dijadikan landasan teoritik dalam penelitian 


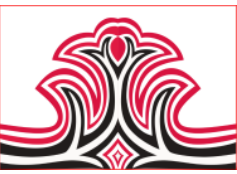

ini) yang menempatkan pembaca sebagai tokoh penting dalam perkembangan karya sastra yaitu Wolfgang Iser. Iser beranggapan bahwa karya sastra merupakan bentuk lain dari komunikasi. Iser mencurahkan perhatiannya pada potensi yang terkandung dalam karya seni agar memberikan efek atau kesan tertentu pada pembaca. Menurut Iser, dalam karya sastra terdapat "tempat kosong", yang pengisiannya diserahkan pada pembaca. Tempat kosong yang dimaksud ialah dalam sudut pandang resepsi, karya sastra bersifat polisemi yang berarti bentuk bahasa (kata atau frasa) mengandung makna lebih dari satu. Oleh karena itu, banyaknya kemungkinan makna yang terkandung dalam karya sastra, maka proses pembacaan dianggap suatu bentuk upaya mengisi ruang lain untuk diberi makna. Dengan begitu, tempat kosong mengaktifkan daya cipta pembaca dan sekaligus menciptakan apa yang disebut innerperspektif. Dengan kata lain, pembaca diajak untuk menginterpretasikan sendiri makna-makna dalam karya sastra, membentuk dunia sendiri sesuai dengan imajinasinya, menjadi tokoh di dalamnya, hingga ikut merasakan apa yang dirasakan tokoh dalam karya tersebut. Lebih jauh, pembaca dapat memberi kesan (wirkung) melalui pernyataan, apa yang dirasakan dan dipahami dari karya yang dibaca hingga bagaimana kemudian pembaca bersikap. Iser menyebutnya sebagai pembaca implisit.

Agar dapat melaksanakan teori yang diajukan Iser, maka peneliti menerapkan cara sinkronis. Pradopo (2007) menerangkan bahwa penelitian sinkronis merupakan penelitian resepsi terhadap sebuah teks sastra dalam periode tertentu. Penelitian resepsi dengan metode ini dapat dilakukan dengan cara teks disajikan pada pembaca, baik secara perorangan maupun berkelompok, agar mereka memberi tanggapan pada teks tersebut. Tanggapan pembaca dipancing dengan mengajukan beberapa daftar pertanyaan. Oleh karena itu, penelitian resepsi sinkronis ini dapat digolongkan sebagai penelitian eksperimental. Penelitian dengan cara tersebut dapat juga dikatakan bersifat improvisasi, namun dengan cara itu pula dapat didekati dan diteliti bagaimana kesan pembaca terhadap suatu karya sastra.

\section{METODE PENELITIAN}

Penelitian dilaksanakan dengan metode deskriptif kualitatif. Data dikumpulkan dengan cara observasi, dokumentasi, melakukan wawancara - terencana maupun tidak terencana - kepada masyarakat yang dianggap relevan, wawancara yang berlandaskan pada ingatan sebagai sumber informasi, serta studi pustaka.
Gorga Jurnal Seni Rupa

Volume 09 Nomor 01 Januari-Juni 2020

p-ISSN: 2301-5942 | e-ISSN: 2580-2380

Observasi atau pengamatan bertujuan mengetahui sesuatu dari sebuah fenomena yang didasari pada pengetahuan dan gagasan yang bertujuan untuk memperoleh informasi-informasi terkait dengan suatu fenomena atau peristiwa yang sudah atau sedang terjadi. Mengacu pada pengertian tersebut, peneliti meninjau langsung ke lapangan, yaitu Krueng Dho dan Krueng Daroy untuk mengamati kondisi di sekitar. Berdasarkan hasil dari observasi, maka dapat ditentukan perihal yang relevan hingga dapat memudahkan berjalannya proses penelitian selanjutnya.

Setelah melakukan observasi, maka selanjutnya dilakukan dokumentasi atas objek yang sekiranya dianggap relevan. Proses ini dimaksudkan secara spesifik, yaitu mendokumentasikan objek penelitian dalam bentuk foto. Melalui foto-foto ini dapat diketahui lebih jelas bagaimana bentuk-bentuk objek yang akan diteliti. Lebih jauh, setelah dilakukan observasi dan dokumentasi, dapat dipetakan informan yang dianggap berkapasitas atau terkait dengan objek penelitian.

Tahapan selanjutanya yaitu melakukan wawancara berdasarkan pada informan yang telah dipetakan dalam tahap penelitian sebelumnya. Wawancara dilakukan dengan terencana dan tanpa terencana (Jane Stokes, 2007). Wawancara terencana dimaksudkan berawal dari pertanyaan yang mula-mula disiapkan untuk setiap informan guna mengetahui pandangan umum tentang bagaimana pandangan masyarakat dalam memaknai karya seni mural. Sebaliknya, wawancara tanpa terencana ialah proses penelusuruan informasi kepada informan yang sekiranya berkapasitas untuk menjawab tanpa adanya pertanyaan-pertanyaan yang disiapkan serta dalam rentang waktu yang tidak ditetapkan.

Proses wawancara juga melakukan metode bagaimana ingatan dapat dijadikan sebagai sumber informasi (James Danandjaja, 1988). Informasi yang nantinya disampaikan oleh narasumber akan diseleksi, sebelum dilakukan proses penyeleksian - informan akan dibiarkan bercerita tentang bagaimana pengalamannya dalam mengapresiasi karya seni mural. Peneliti meyakini dengan membiarkan informan bercerita tentang pengalamannya - akan dapat ditemukan bagaimana pandangan informan, pernyataan yang dianggap peneliti bermanfaat dalam proses membangun hasil penelitian. Metode tersebut dikenal dengan model wawancara naratif. 
Disamping itu, peneliti juga melakukan studi pustaka (cetak maupun daring) untuk melihat hal-hal yang sekiranya luput dari amatan langsung di lapangan.

\section{HASIL DAN PEMBAHASAN}

1.Hasil

elit Melihat karya seni mural yang terdapat di Krueng Dho dan Krueng Daroy, sebagian besar dominan dengan gambar makhluk hidup (yang memiliki ruh), baik manusia maupun hewan. Jika sebagian gambar (terutama hewan) yang terdapat di Krueng Dho cenderung realistik, di Krueng Daroy justru dominan dengan gambar manusia namun tidak begitu realistik. Lebih lanjut, gambar-gambar tersebut kemudian menyimpan suatu persoalan, yakni berupa fakta yang kontradiktif. Sebagaimana disinggung dalam pendahuluan bahwa salah satu syari'at Islam ialah melarang membuat gambar yang menyerupai makhluk yang bernyawa atau memiliki ruh.

Meskipun begitu, bagi masyarakat Krueng Dho dan Krueng Daroy, lukisan yang cenderung realistik tersebut berfungsi sebagai ruang edukasi untuk masyarakat, baik anak-anak maupun orangtua. Tujuan edukasi tersebut beragam, di antaranya agar masyarakat mengetahui sebagian dari sejarah Aceh, atau lebih mengenal alam, bagaimana pentingnya alam bagi kehidupan manusia, sehingga masyarakat tahu pula bagaimana menjaga dan sebagainya. Munculnya visi tersebut merupakan refleksi dari kondisi bantaran Krueng Dho dan Krueng Daroy yang terlihat perlu adanya penjagaan/perawatan dari masyarakat setempat serta dukungan dari pemerintah kota, sehingga dapat menyamarkan kesan kawasan kumuh yang disematkan pada bantaran tersebut.

Salah satu masyarakat Krueng Dho, Dani Cahyadi Aji, ketua salah satu Kelompok Swadaya Masyarakat (KSM) di Dusun Kerinci menyatakan; "memang, di tengah masyarakat Aceh yang pedoman hidupnya berlandaskan pada syaria'at Islam, gambar tersebut tentu terlihat janggal. Namun, bagi kami, tidak ada maksud selain bagaimana kami memfungsikan karya seni ini, yaitu untuk memperindah kawasan tempat kami tinggal. Jadi dengan begitu, sekiranya tidak ada masalah dari sudut pandang Islam. Begitu pun pandangan dari para ulama, ada sebagian melarang dan ada pula yang membolehkan. Di lain sisi, dengan adanya kegiatan ini dapat membangkitkan semangat gotong royong warga. Pendek kata, cukup banyak hal baik yang didapat warga dari kegiatan ini."

Di samping itu, kemungkinan karya seni mural untuk menunjang perekonomian serta kepariwisataan masih
Gorga Jurnal Seni Rupa

Volume 09 Nomor 01 Januari-Juni 2020

p-ISSN: 2301-5942 | e-ISSN: 2580-2380

jauh dari cukup. Dani menambahkan, “dengan kondisi seperti sekarang ini, memang sangat jauh dari cukup bantaran Krueng Dho ini menjadi tempat wisata. Karena di bantaran ini perumahan, sebagian masyarakat ialah penyewa. Namun setidaknya, bagi masyarakat Krueng Dho sendiri, dengan adanya gambar dapat merubah kesan kurang baik yang dilihat oleh masyarakat luar. Kalaupun ada orang yang datang, itu waktu rumah ini siap dilukis dan masingmasing dengan tujuan yang berbeda-beda. Sebagian orang datang dari stasiun televisi atau koran lokal untuk meliput berita dan sebagian lainnya ada juga mahasiswa dengan tujuan penelitian. Namun itu cuma sesaat. Sekarang ini hanyalah masyarakat yang menikmati."

Tanggapan warga Krueng Dho kurang lebih senada dengan masyarakat Krueng Daroy. Majid, salah satu warga Krueng Daroy berpandangan; "Bagi orang yang merenungi gambar ini, gambar tersebut dapat memancing inspirasi. Namun saya menyarankan gambar yang dilukis cenderung berbentuk kaligrafi atau tokoh-tokoh pahlawan Aceh. Di lain sisi, ini kan taman, tentunya gambar ini dapat menghibur, terutama anak-anak. Jadi diterima atau tidaknya gambar ini oleh masyarakat tergantung fungsi dan bagaimana masyarakat mengartikan."

Salah satu warga Krueng Daroy lainnya, M. Yusuf Abi, bahkan menyatakan pandangan yang menekankan pada kualitas gambar; "Baiknya gambar ini terlihat lebih mirip lagi, kalau dilihat, salah satu gambar terlihat cukup kaku. Karena ini kan sejarah, tentu gambar ini dapat memberi pengetahuan pada masyarakat. Namun sejarah digambarkan oleh lukisan yang berkualitas pula. Dengan begitu, makna yang terkandung dalam gambar dapat cepat ditangkap oleh masyarakat. Karena posisi gambar ini di pinggir perlintasan warga berjalan kaki. Misalnya, seperti menggambar Cut Nyat Dien, apabila gambar terlihat kaku atau seperti kartun, tentu masyarakat akan bingung melihat gambar. Ini gambar siapa? Tapi apabila dibuat lebih mirip, masyarakat akan cepat mengetahui, itu gambar Cut Nyak Dien, pejuang kemerdekaan Indonesia asal Aceh.'

Berdasarkan tanggapan dari masyarakat di atas, tidak ditemui pertentangan antara gambar yang realistik dengan syaria'at Islam. Pertentangan tidak muncul dikarenakan resepsi masyarakat yang menganggap karya seni mural hanyalah berbatas memberi keindahan bagi yang melihat dan dapat menyampaikan suatu pengetahuan, bukan merasakan takjub yang berlebihan sehingga bertentangan dengan 


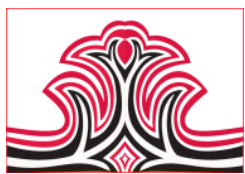

syari'at. Di samping itu, kondisi Krueng Dho dan Krueng Daroy saat ini tidak cukup berpotensi untuk menjangkau/menarik minat wisatawan dalam waktu jangka panjang atau meningkatkan perekonomian masyarakat. Kalaupun didapati masyarakat yang berdagang, terutama di Krueng Daroy, belum cukup untuk menunjang perekonomian masyarakat banyak secara signifikan.

\section{Pembahasan}

Bantaran Krueng Dho dan Krueng Daroy, Dusun Kerinci, Gampong Setui, Kecamatan Baiturrahman, Kota Banda Aceh tergolong kawasan kumuh. Anggapan itu muncul dikarenakan kawasan tersebut padat penduduk yang terlihat dari jajaran rumah $\mathrm{di}$ sepanjang bantaran. Jajaran rumah yang sekaligus rapat/padat juga mengesankan kesemrawutan.

Menimbang kondisi tersebut, pemerintah kota berinisiatif memperindah bantaran. Maka kemudian, pemerintah kota memutuskan bahwa karya seni mural sekiranya dapat mengatasi permasalahan yang ada. Guna menjalankan inisiatif tersebut, pemerintah kota membuat program Kotaku (Kota Tanpa Kumuh) bekerjasama dengan masyarakat Krueng Dho serta dosen dan mahasiswa Jurusan Seni Rupa dan Desain ISBI Aceh. Rumah-rumah penduduk pun dilukis dengan beragam bentuk gambar sehingga terlihat indah dan menarik.

Pada dinding rumah warga tidak hanya ditemui gambar-gambar yang dilukis oleh dosen dan mahasiswa Jurusan Seni Rupa dan Desain ISBI Aceh, warga pun juga turut menunjukkan kemampuannya dalam bermain-main dengan warna. Bentuk gambar yang dilukis warga pun beragam, seperti ikan hiu, kupu-kupu, dan burung. Bahkan gambar yang dilukis warga cenderung terlihat realistik. Gambar dengan sengaja dilukis menggunakan warna-warna cerah, seperti kuning, merah, hijau, biru, orange. Warnawarna cerah dapat dikatakan strategi, menggiring persepsi, agar muncul perasaan nyaman bagi yang melihat, seperti yang terdapat pada gambar 4, 5 dan 6 di bawah ini:
Gorga Jurnal Seni Rupa

Volume 09 Nomor 01 Januari-Juni 2020

p-ISSN: 2301-5942 | e-ISSN: 2580-2380

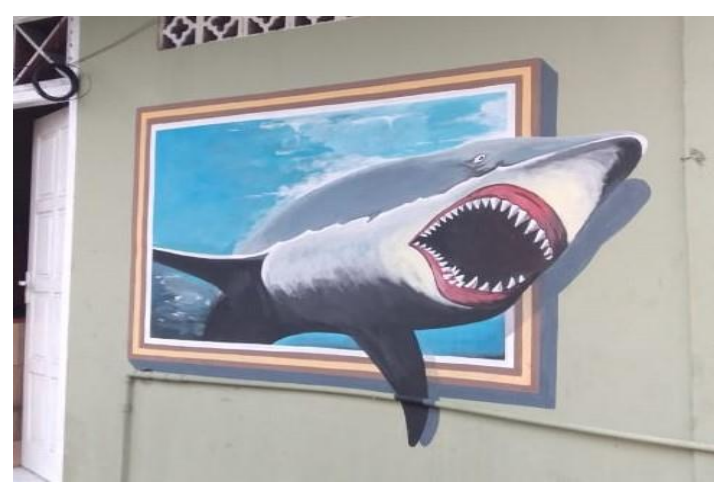

Gambar 1. Ikan hiu tiga dimensi pada dinding rumah warga di Krueng Dho (Sumber: Hatmi Negria Taruan, 2019)

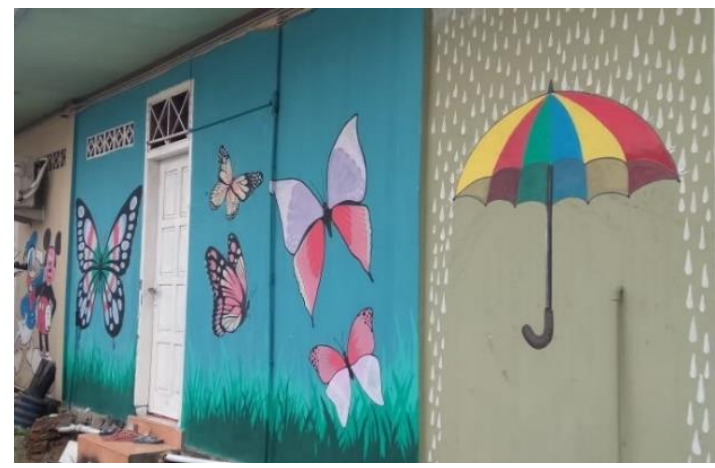

Gambar 2. Lukisan hujan dan payung, kupu-kupu, serta Mickey Mouse pada dinding rumah warga di Krueng Dho (Sumber: Hatmi Negria Taruan, 2019)

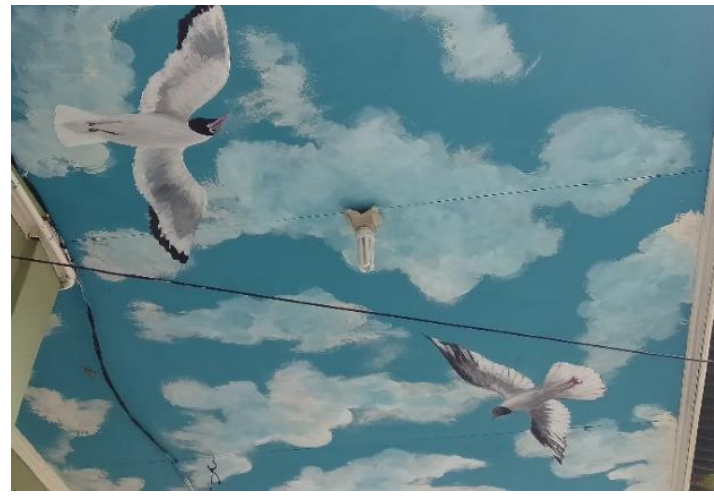

Gambar 3. Lukisan burung di langit-langit rumah warga di Krueng Dho (Sumber: Muhammad Ghifari, 2019)

Sedikit berbeda dengan bantaran Krueng Daroy sebelum direnovasi, berdasarkan keterangan warga, Khairun dan Zulrahmat, kondisi di sepanjang bantaran masih berupa hamparan tanah yang hanya memungkinkan dilewati pejalan kaki. Di malam hari, bantaran Krueng Daroy gelap tidak ada penerangan. Tidak memungkinkan dalam kondisi tersebut suasana di sepanjang bantaran menjadi "hidup". Berbeda halnya dengan sekarang, kawasan kumuh yang disematkan tidak lagi sepadan dengan bagaimana kawasan tersebut terlihat. Saat ini bantaran telah ditutupi semen, dipagari besi, serta telah dipasangi lampu sebagai penerang bagi pejalan kaki. Sebagian ruas tanah dijadikan taman untuk masyarakat bersantai atau bermain. 

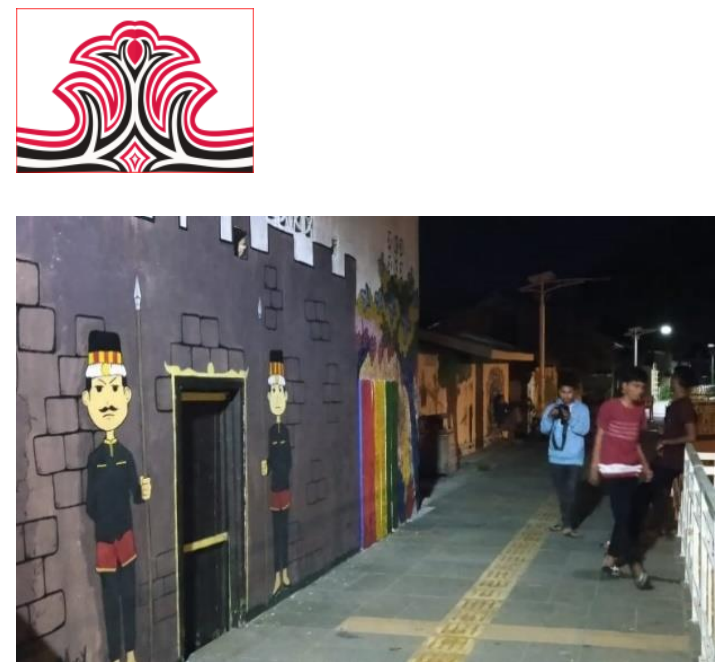

Gambar 4. Remaja berswadaya foto berlatar karya mural di bantaran Krueng Daroy (Sumber: Susandro, 2019)

Karya seni mural terdapat di pagar dan dinding rumah warga secara terpisah. Adapun gambar yang terlihat ialah dua orang prajurit yang memegang tombak sedang berjaga di sisi kanan dan kiri gerbang, gambar pohon, seorang tuan dan prajurit yang sedang memegang senjata berdiri di bawah pohon. Gambar tersebut jelas terlihat tidak terikat dalam satu tema.

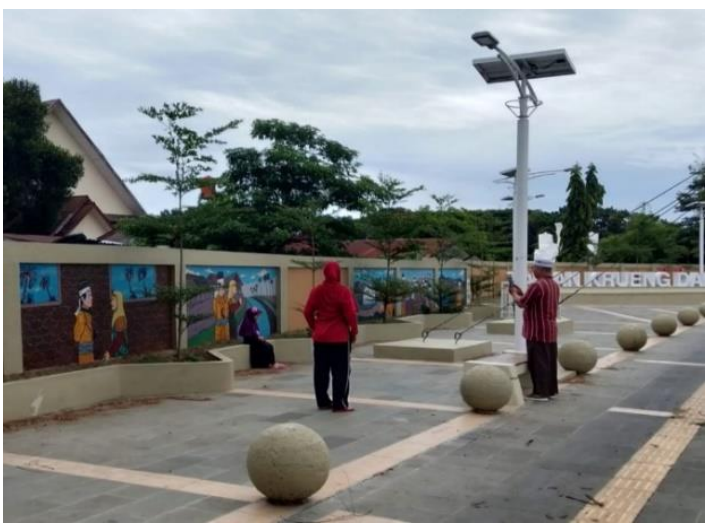

Gambar 5. Sembari berolahraga pagi, masyarakat menyempatkan berfoto di depan karya seni mural di bantaran Krueng Daroy (Sumber: Susandro, 2019)

Di sisi lain, karya seni mural pada gambar 8 terlihat cukup runtut, dikarenakan gambar tersebut menceritakan sejarah bagaimana bantaran Krueng Daroy dibangun dengan membaca fragmen gambar.

Sepanjang paparan di atas, gambar yang terdapat di Krueng Dho dan Krueng Daroy terlihat variatif. Gambar di Krueng Dho tidak terikat oleh satu tema, begitu pula dengan gambar di Karueng Daroy. Gambarnya pun tidak terikat oleh satu bentuk, realistik atau komik. Sebagian gambar berbentuk komik dan sebagiannya lagi realistik. Akan tetapi, baik di Krueng Dho dan Krueng Daroy, menunjukkan kesepadanan warna, yakni marna cerah. Jadi tidak berlebihan sekiranya diasumsikan bahwa dengan dominasi warna cerah dapat menyamarkan kesan kawasan kumuh yang disematkan pada bantaran Krueng Dho dan Krueng Daroy.
Gorga Jurnal Seni Rupa

Volume 09 Nomor 01 Januari-Juni 2020

p-ISSN: 2301-5942 | e-ISSN: 2580-2380

\section{KESIMPULA DAN SARAN}

\section{Kesimpulan}

Sejauh ini dapat disimpulkan bahwa karya seni mural yang menggambarkan makhluk hidup yang bernyawa atau memiliki ruh tidak menjadi persoalan selama bagaimana masyarakat memfungsikan dan memaknai karya tersebut. Bagi masyarakat kota Banda Aceh, terutama warga Krueng Dho dan Krueng Daroy, karya seni mural hanyalah karya seni. Lebih tepatnya masyarakat hanya mencoba 'memaknai fungsi' dari karya seni, kalaupun masyarakat mencoba memaknai, tidak lebih dari makna keindahan secara umum. Oleh karena itu, meski karya seni mural menggambarkan makhluk yang bernyawa atau memiliki ruh dan cenderung nampak realistik, bagi masyarakat Krueng Dho dan Krueng Daroy, gambar tersebut dapat difungsikan untuk menarik minat masyarakat pada umumnya sehingga dapat merubah kesan kawasan kumuh yang disematkan sebelumnya.

\section{Saran}

Seyogianya kedepan, khususnya di Aceh, perlu dilakukan kajian-kajian karya seni dari sudut pandang syari'at Islam. Meninjau bagaimana masyarakat dapat menerima karya seni dan syari'at Islam secara bersamaan. Atas dasar pengetahuan itu pula, harapannya dapat melahirkan strategi-strategi berkesenian yang berimbang, yaitu menjadi jaminan bagi kesenian itu sendiri agar dapat terus berkembang serta bermanfaat pula bagi masyarakat sekitar.

\section{DAFTAR RUJUKAN}

Danandjaja, James. (1988). Antropologi Psikologi, Teori, Metode dan Sejarah Perkembangannya. Jakarta: Rajawali.

Junus, Umar. (1985). Resepsi Sastra: Sebuah Pengantar. Jakarta: Gramedia.

Pradopo, Rachmat Djoko. (2007). Beberapa Teori Sastra, Metode Kritik, dan

Penerapannya. Yogyakarta: Pustaka Pelajar. Stokes, Jane. (2007). How to do Media and Kultural Studies: Panduan Untuk Melaksanakan Penelitian dalam Kajian Media dan Budaya. Terj. Santi Indra Astuti. Yogyakarta: Bentang. Susanto, Mike. (2012). dalam Asharhani, Imaniar Sofia. "Mural dan Graffiti sebagai Elemen Pembentuk Townscape". Depok: Universitas Indonesia.

Wicandra, O. B. (2009). Berkomunikasi Secara Visual Melalui Mural di Yogyakarta. Jurnal Desain Komunikasi Visual Nirmana. Diunduh 3 November 2019 [Online]. Di http://nirmana.petra.ac.id 
https://id.wikipedia.org/wiki/Hukum_jinayat_d p-ISSN: 2301-5942 | e-ISSN: 2580-2380 i_Aceh, diakses 3 November 2019. 